\title{
CHRIST'S CRUCIFIXION AS A MEDICO-HISTORICAL EVENT
}

\begin{abstract}
The crucifixion of Christ as a medico-historical event is reviewed. He was probably crucified on a short Tau-cross, and died within 6 hours (probably even within 3 hours). This is not an exceptionally short period of time, and there is no reason to postulate unusual causes for his death. He probably died from the classical progressive asphyxia syndrome and hypovolaemic shock typical of the crucifixion process, finally ending in cardiac arrest as result of a vaso-vagal reflex. The latter could have been elicited by intense pain due to various causes, although hypoxaemia per se or various other less common conditions could also have pertained. The wound in Christ's side from the spear which probably pierced his heart, was certainly inflicted after his death. The appearance of blood and water as an expected post mortem phenomenon is discussed. There is no reason to consider this as proof of a functioning blood circulation indicating apparent rather than true death. Although the two robbers who were crucified with Christ were apparently still alive when He died, they were dispatched shortly afterwards by crurifragium.
\end{abstract}

\section{INTRODUCTION}

Christ's crucifixion is central to the salvation history of Christianity. For the Romans and the orthodox Jews of the $1^{\text {st }}$ century, who considered crucifixion an intensely shameful and gruesome form of execution, the event was a paradox (Fitzmyer 1978:493-4, 511; Torrance 1990:2453-4). In one of the earliest attacks on Christianity, Celsus ( $2^{\text {nd }}$ century) mocks the Christian position and questions a faith which would allow a divine prophet to die in such a completely dishonourable way. ${ }^{1}$ The thought that such a brutal and shameful death could be considered as the greatest sacrifice of all time, or as the means to salvation, was unknown and inconceivable within the ethos of the time (Fitzmyer 1978:493-4).

This study will focus not on those historical aspects of the crucifixion which have previously been thoroughly considered, but rather on the medical evaluation of historical details, in the light of modern medical science - an aspect which has not yet received due attention.

1 Contra Celsum vii. 53. 


\section{SOURCES}

Crucifixion is defined as execution by hanging on a cross or a similar structure, usually by the hands and arms, until the victim expires. It should be distinguished from the ancient Jewish custom whereby execution (usually by stoning) was followed by post mortem hanging on a pole, tree or other structure. ${ }^{2}$

The main historical sources relating to Christ's crucifixion are to be found in the New Testament. The earliest references, written about two decades after the event (AD 53-55), are in Paul's epistles. ${ }^{3}$ The complete history of the Passion was described between AD 60 and 100 in the four Gospels, first in Mark, then in Matthew and Luke, and finally in John (Kuhn 1982:670-677). The apocryphal Gospel of Nicodemus refers to the crucifixion, but will not be discussed here as it was written only in the $4^{\text {th }}$ century (Muller 1976:26-43).

Non-Biblical sources include a brief reference in the Annals (XV. 44.3) of the Roman historian Tacitus (c. AD 115), which mentions Christ's judgement by Pilate, but not the manner of his death. A contemporary, Suetonius, writes in his Divus Claudius (c.25) of a Jewish revolt in the time of Claudius Caesar (AD 41-54), led by one Chrestus. If the dating is not taken too literally (since the text was penned about a century after the event), this may also refer to Christ.

Non-Roman writers who make mention of the crucifixion include Celsus (above) and the $2^{\text {nd }}$ century satirist Lucianus of Samatosa who mentions a man crucified in Palestine for establishing a new cult. ${ }^{4} \mathrm{~A}$ Christian writer of the $3^{\text {rd }}$ century, Julius Africanus, quotes an earlier Samaritan historian, Thallos, who links Christ's Passion with a solar eclipse of the year 29. However, Kuhn (1982:663) has demonstrated that it is difficult to verify the historicity of Thallos's fragmentary writings.

Flavius Josephus, a $1^{\text {st }}$ century Jewish historian, describes Jesus' death and resurrection in his Testimonium Flavianum. ${ }^{5}$ It has been questioned

2 Deut. 21:22, 23.

31 Cor. 11:23-25 and 15:3-5; and slightly later Col. 2:14; Gal. 3:13 and Phil. 2:6-11.

4 The Passing of Peregrinus, c.11.

5 Jewish Antiquities XVIII. 63. 
whether this chapter is authentic (Kuhn 1982:660); it may be a later addition by a Christian writer (Feldman 1930:49). In addition, there is the "Syrian text", a letter from a $2^{\text {nd }}$ or $3^{\text {rd }}$ century Syrian prisoner in a Roman jail to his son, mentioning the execution of a wise Jewish leader (in all probability, Christ) (Kuhn 1982:664).

In a survey of Rabbinical literature from the $1^{\text {st }}$ century to the $3^{\text {rd }}$, Kuhn (1982:665-9) has discovered evidence of likely references to Christ - a person called Jesus, "hanged" by the Jewish authorities on the eve of the Passover on charges of sorcery and rabble-rousing. The word "hanged" may be interpreted in this context as referring to crucifixion.

The Shroud of Turin, a piece of linen approximately one by three metres, bearing what appears to be the imprint of a crucified figure, is considered by some to be the shroud of Christ (Barbet 1963:1-36), but such claims are now generally viewed with scepticism since Carbon-14 dating has established that it dates from between 1260 and 1390 (Long 1998:1). It may have been made in the Middle Ages to be viewed during liturgical dramas in the Near East (Kane 1990:151-4). The debate rages on, however, as may be seen from ongoing contributions to several internet sites.

\section{THE CRUCIFIXION}

\subsection{The flagellation}

In terms of Roman law, all those sentenced to death, with the exception of women, Roman senators and soldiers (other than deserters), were to be flagellated, and this was also the case with Jesus before his crucifixion. According to Matthew 27:26 and Mark 15:15, the flagellation was apparently in preparation for the crucifixion, but in Luke 23:16 and John 19:1-4 it appears as if Pilate intended the flagellation as a punishment in its own right, and possibly instead of crucifixion. It is clear from the texts that the soldiers responsible for the flagellation also subjected Christ to further torment and scorn before the journey to Golgotha.

Flagellation was a particularly brutal procedure (Schulte 1963: 177-8; Edwards et al. 1986:1457-8), inflicted with canes or a short whip (flagellum, flagrum) comprising a number of leather thongs into which pieces of metal or bone had been plaited. The victim was tied, naked, 
to a post facing the spectators, and beaten on the back, buttocks and thighs by one or two soldiers (lictores). Primrose (1949:384) is of the opinion that victims were also beaten on the front of the body. In Roman law there was no restriction on the number of lashes, which was left to the lictores to decide. Jewish law limited the punishment to 40 lashes. Flagellation was intended to weaken the condemned man by means of deep, grievous wounds, bleeding and almost intolerable pain. Deepseated injuries such as fractured ribs and pleural (or even pericardial) effusions sometimes occurred. Victims often lost consciousness. Sudden death was not uncommon (Kuhn 1982:752), probably due to vasovagal cardiac arrest (see below). Jesus was almost certainly flagellated according to the Roman procedure, with an unlimited number of lashes thus being inflicted.

After flagellation, the victim would be subjected to derision and to further pain, often including mutilation such as blinding or the excision of the tongue or other parts of the body (Kuhn 1982:756). Josephus ${ }^{6}$ describes a particularly cruel instance when a condemned man's child was throttled and then hung around his neck on the orders of Antiochus IV.

\subsection{The procession}

According to Mark 15:18-20, after the flagellation Christ was re-clothed in his own garments and ordered to carry the cross to the place of crucifixion. John 19:17 tells us that Christ carried his cross alone, but according to Matthew 27:32, Mark 15:21 and Luke 23:26, Simon of Cyrene was ordered to carry it (possibly because Christ was too weak after the flagellation).

The Roman custom was that the condemned would carry their crosses naked, but possibly due to Jewish abhorrence of nakedness, an exception was made for Christ (Edwards et al. 1986:1459). Although there is no Biblical evidence for this, it is probable that Christ, according to Roman custom, carried only the cross-bar (patibulum), rather than the whole cross, which would have been extremely heavy (Collins 1939:156-7; Schulte 1983:178; Edwards et al. 1986:1459). At venues where crucifixions regularly occurred, the vertical bar (stipes) was usually a permanent fixture. The patibulum (weighing about 50-60 kilograms)

6 Jewish Antiquities XII.256. 
was placed over the shoulders of the condemned man, and tied to his arms. The titulus, on which his name and his offence would be written, was carried at the head of the procession, while bystanders mocked and derided.

Such a crucifixion would be carried out formally by a Roman guard under the leadership of a centurion, who would remain on the scene until the condemned man died (Edwards et al. 1986:1459).

\subsection{Types of crosses}

Crucifixion probably originated in ancient Assyria and Babylon, but was first systematically used by the Persians. The condemned were originally hanged from trees or poles, but in the course of time, the cross developed. The Romans perfected crucifixion over five centuries, until it was prohibited by Constantine the Great in the $4^{\text {th }}$ century (Kuhn 1982:679-775).

We have no definite information regarding the type of cross on which Jesus was crucified, but it is likely that it was a Latin or Tau cross. At this time the Romans used both the wooden Latin cross, or crux immissa $(\dagger)$, and the Tau cross, or crux commissa $(\mathrm{T})$, but most often the latter, with the victim's feet less than a meter above the ground (Edwards et al. 1986:1458). Crosses in the shape of an X (the crux decussata), simple crossbars between two vertical poles, and even single posts (the crux simplex) were also used (Schulte 1963:178). It has also been suggested that Jesus was crucified on a single post (Van der Watt \& Joubert 1996:644-51).

Crosses could stand tall (the crux sublimis) but were usually short (the crux bumilis): 1,8 to 2,4 meters high, with a patibulum of 1,5 to 1,8 meters and a total weight which could exceed 130 kilograms. The inscription (titulus) would be nailed to the stipes above the victim's head. Sometimes a wooden block was nailed to the stipes as a prop for the buttocks (sedile, sedicula), but there was seldom any support for the feet (suppedaneum).

\subsection{The place of crucifixion}

Jesus was executed at an established place of crucifixion (outside the city walls, as was the custom) called Golgotha (Calvary, the place of the 
skull). ${ }^{7}$ It is not known whether this name indicates that there were often skulls bestrewn around the area, or that it was on a hill which resembled a skull.

Two places are traditionally identified as the location of Golgotha. In 1849, Gordon identified a hill outside the city walls of Jerusalem which looked like a skull as possibly the original Golgotha. There is no other evidence for this view, however (Payne 1990:161-2). The other, more probably location, is on the site of the present Church of the Holy Sepulchre. After Jerusalem had been destroyed by the emperor Titus in AD 70 and Hadrian had exiled the Jews from Palestine in 135, settling other inhabitants there, Jerusalem was renamed "Aelia Capitolina", and the topography of the area underwent significant alteration. There is evidence, moreover, that Hadrian purposely sited a temple of Venus on the erstwhile Golgotha in order to desecrate it in the eyes of the Christians (Kane 1990:153-4). After the Roman Empire adopted Christianity as its official religion in the $4^{\text {th }}$ century, Constantine the Great's mother made a pilgrimage to Jerusalem, and was shown this location, on which the Church of the Holy Sepulchre was then built (Payne 1990:161-2).

\subsection{The process of crucifixion}

The Gospels give only limited details of the procedure. We are told that a mixture of wine and myrrh, or incense, was offered to Jesus, which he declined. ${ }^{8}$ His clothes (both under- and over-garments) were divided among the soldiers. ${ }^{9}$ Two men, probably thieves, were crucified along with him, one on either side. ${ }^{10}$ Also present were a crowd of mocking bystanders, ${ }^{11}$ the women who followed him, ${ }^{12}$ and, at a distance, other friends. ${ }^{13}$

7 Matt. 27:32-4.

8 Matt. 27:34; Mark 15:23.

9 Matt. 27:35; Luke 23:34; John 19:23-4.

10 Matt. 27:38.

11 Matt 27:38-44; Mark 15:32.

12 John 19:25-6.

13 Luke 23:48. 
According to Jewish law, it was the custom to offer the condemned man a mild sedative of wine with myrrh, or incense (Schulte 1963:178). In terms of Roman procedure Jesus should have been crucified naked, and it is not known whether, as on the procession to Golgotha, he was permitted to wear the minimum of clothing (Edwards et al. 1986:1458-9).

The usual procedure for crucifixion was that the condemned man was forced into a supine position, with his arms stretched out along the patibulum, so that they could be tied or nailed to it. In the latter instance, as probably occurred in the case of Jesus, square iron nails of about 13 to 18 centimetres in length and a centimetre across were used. These were hammered into the crossbar through the wrists or the forearms, rather than the hands, since the body's weight would cause the nails in the hands to tear loose. The body and the crossbar were then raised and attached to the stipes with a mortise and tenon joint, or in any other suitable manner, with the flagellated back of the victim against the rough vertical bar (Edwards et al. 1986:1548-61). After this, the pendant feet were attached to the cross. If this was done by nailing, there were various methods: the feet could be placed one across the other, with the soles towards the stipes and the knees slightly bent, so that they could be fixed from the front, with a single nail through the tarsal bones. The feet could also be placed next to each other and turned sideways, and a nail driven through both heel bones into the stipes (Schulte 1963: 178-9; Edwards et al. 1986:1459-60). Other positions were sometimes used, such as inverted crucifixion, or even with one foot and one arm attached to the crossbar. ${ }^{14}$

\subsection{On the cross}

The Bible does not place great emphasis on the physical suffering of Christ on the cross. According to the synoptic Gospels, He was crucified at about nine in the morning, ${ }^{15}$ but John gives the time as twelve, or even later. ${ }^{16}$ By noon darkness had descended on the area, which lasted about three hours. ${ }^{17}$ Jesus spoke several times from the cross and

14 Josephus, The Jewish War 5.551.

15 Mark 15:25.

16 John 19:13.

17 Matt. 27:45; Mark 15:33; Luke 23:44. 


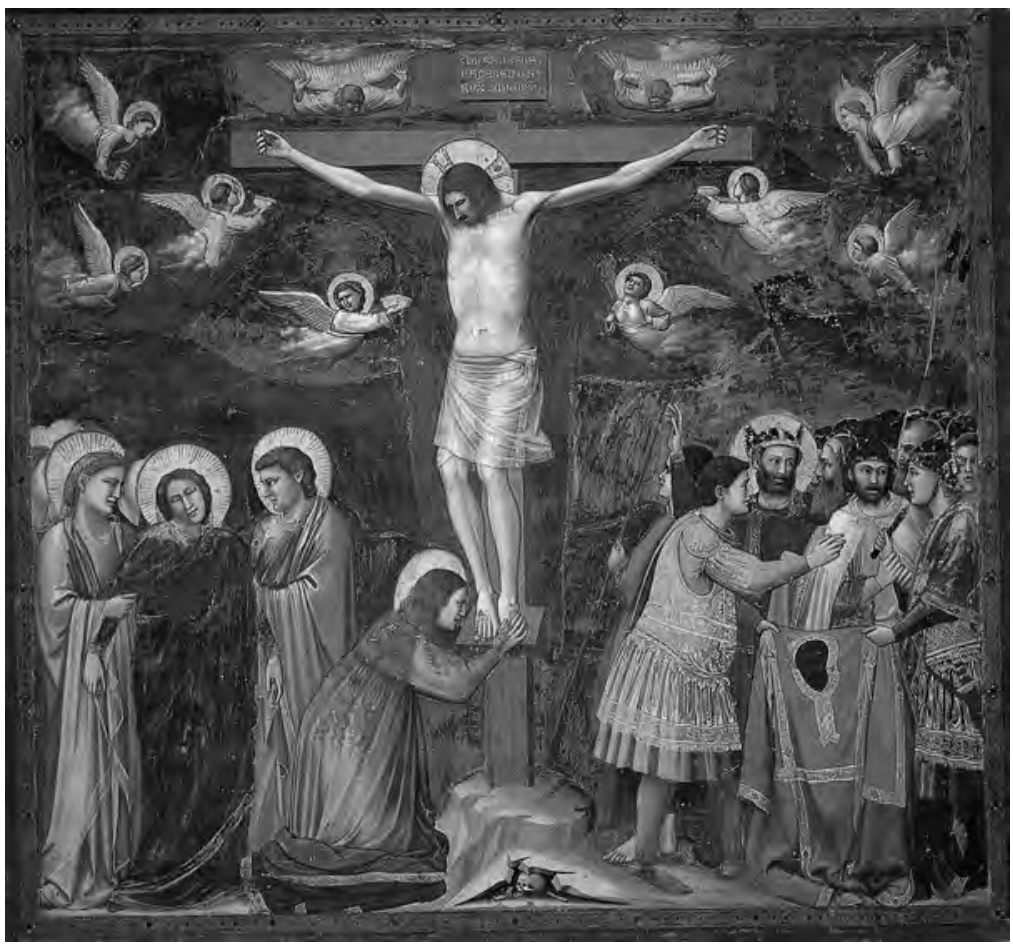

Figure 41: "The Crucifixion" by Giotto, a fresco in the Scovegni Chapel, Padua.

at around three in the afternoon He said that He was thirsty. A sponge dipped in sour wine was lifted to his mouth. Barbet (1963:89-102) postulates that this drink was probably posca (vinegar or wine, mixed with water and beaten egg) — the daily drink of soldiers. After this, Jesus cried out in a loud voice and then died. ${ }^{18}$ The synoptic Gospels also tell us that the veil of the temple tore of its own accord from top to bottom, that there was an earthquake, and that graves were burst open. ${ }^{19}$ When Joseph of Arimathea asked Pilate for the body of Jesus

18 John 19:30; Luke 23:45.

19 Matt. 27:51. 
shortly after this, the governor was surprised to hear that Jesus was already dead, and first established the truth of this tiding with the centurion. ${ }^{20}$ The soldiers broke the legs of the two thieves to confirm (or cause) their death, but they found it unnecessary to do so to Jesus, since He was already dead, as indicated when they pierced His side (pleura) with a spear, producing water and blood. ${ }^{21}$ Jesus' body was then removed from the cross, wrapped in linen and placed in an unused tomb of rock, the intention being to complete the burial preparations after the Sabbath, which was close at hand. ${ }^{22}$ Jesus thus died after hanging for about six hours on the cross according to the synoptic Gospels, but for only three hours according to John.

Crucifixion involved terrible physical and psychological pain and shock. Kuhn (1982:747) notes that the three most brutal punishments of ancient times were crux (crucifixion), crematio (immolation) and decollatio (decapitation) - in that order. Crucifixion involved pain from a multiplicity of causes: from the flagellation; from continuous aches and muscle cramps in the arms and shoulders, due to the pendant position; from the wounds in the wrists and feet, where major nerves would have been damaged, so that every movement of the ankles or wrists would have caused pain to shoot through the limbs. Death would sometimes occur after four to six hours, but more usually within one or two days, and sometimes after as long as four days (Edwards et al. 1986:1460).

There were various ways to hasten or confirm the death of a victim. The soldiers supervising a crucifixion often resorted to crurifragium - breaking one or both of the bones of the lower limbs (the tibia, and sometimes also the fibula) with a blunt instrument. Sometimes axes or serrated implements were used for the purpose (Haas 1979:57; Schulte 1963:180). The sternum could also be dealt a sharp blow with a club, or a spear could be inserted from below, through the upper abdomen or the chest, in order to pierce the heart. The spear wound inflicted on Jesus would almost certainly have been of this type. Sometimes a fire was lit at the base of a cross and made to smoke, in order to cause suffocation (Schulte 1963:180).

20 Mark 15:44-5.

21 John 19:34.

22 John 19:41; Luke 23:51-61. 
The three hours of darkness during the crucifixion could not have been caused by a solar eclipse, as suggested by Thallos (see above). Complete eclipses of the sun, causing general darkness, last only for minutes, never for hours. We also know that the crucifixion took place at Passover time, which always coincides with a full moon (Num. 9:3-5; Wiseman 1990:159). A solar eclipse is impossible when the moon is at the full (Spencer Jones 1961:200-4).

\section{CAUSES OF DEATH BY CRUCIFIXION}

\subsection{General}

Death by crucifixion was multifactorial in its causes. Apart from the enormous physiological and psychological problems caused by the process of crucifixion itself, the preceding events would usually already have significantly exhausted the body. The judgement and sentencing would have involved significant pschological tension for the victim, which may have been accompanied by insufficient rest, food and fluids. The flagellation would have caused severe trauma — psychological shock, intense pain, loss of blood and fluid from the wounds, as well as varying degrees of damage to deep tissue, particularly muscles and bone. It has been claimed that the severity of a flagellation and the length of time a victim survived on the cross were inversely proportional (Edwards et al. 1986:1460). Primrose (1949:384-5) is of the opinion that significant sympathetic effusions (accumulation of fluid) often occurred in the abdominal, pericardial and thoracic cavities, which hastened death. Sudden death would probably have been the result of pain-induced vaso-vagal cardiac arrest (see below).

On the cross, progressive dehydration would result from the continued loss of fluids (and to a lesser degree of blood) from the multiple wounds, exacerbated by perspiration and a total denial of fluids. In the course of time, the wounds could become infected, causing septicaemic shock, among other things. After a day or two, thrombosis in the blood vessels of the legs could ensue, due to the absence of the normal pumping action of the leg muscles and the reduction in blood circulation. A pulmonary embolism could follow as a fatal complication. 
Cardiac arrest resulting from a vaso-vagal reflex was probably an important cause of acute death in cases of crucifixion. The stimuli which may precipitate such a reflex include intense pain of any origin; pressure on the neck; a hard blow to the chest, abdomen, groin or neck areas; a puncture of the pleura (the membrane lining the thoracic cavity); a sudden expansion of hollow organs such as the alimentary canal or the cervix; a sudden intake of cold water into the nasopharynx (e.g. during drowning), and severe acute hypoxaemia (oxygen deprivation in the blood and tissues) (Schwär et al. 1984:39-41). Many of these conditions would clearly occur during crucifixion.

The most important pathology during crucifixion, however, was progressive asphyxiation due to grave impairment of respiration in the pendant position. Severe muscle spasms in the arms and shoulders would make it almost impossible to raise the body from time to time in order to facilitate respiration. Breathing was thus soon restricted to diaphragmatic movement only (Schulte 1963:179, 182-4; Edwards et al. 1986:1461). Speech depends on active exhalation, and thus every word that Christ spoke from the cross must have caused Him intense pain. Ineffective respiration leads to increasing hypoxaemia which, according to modern research, leads in turn to "Moon's vicious circle": oxygen deficiency increases the diameter and the permeability of capillaries, which leads to congestion, particularly in the lower parts of the body, a well as to the escape of intravascular fluid to extra-vascular tissue, and thus to a decrease in blood volume. This lowers blood pressure and impedes circulation, exacerbating the hypoxaemia and leading to multiple organ failure (Schwär 1984:39-41; Gordon \& Shapiro 1975:64-8). This hypovolaemic shock syndrome has been empirically confirmed by an experiment carried out on a group of medical students who volunteered as guinea-pigs. They were suspended by their arms while their heart and lung functions, as well as the blood gasses, were continuously monitored. After only six minutes, their respiratory volume decreased significantly, blood pressures dropped by about $50 \%$, and pulse rates doubled. After twelve minutes cardio-vascular collapse set in, breathing was restricted to diaphragmatic movement, and mental confusion set in. The experiment had to be aborted after 30-40 minutes, by which time the pain in their wrists had become unbearable (Mödder, quoted in Schulte 1963:179). These experiments 
proved that a sedile and a support for the feet played a useful role in assisting active respiration. However, the humanitarian aspect of such assistance would be questionable in the case of crucifixion, since suffering would merely be prolonged. Indeed, Schulte (1986:179) suspects that sadistic prolongation of suffering was a reason for the use of the sedile and the foot-support.

A blow on the chest from a club would probably have caused death by activating the vaso-vagal reflex. The inhalation of smoke, too, could well have precipitated death for a victim suffering from critical restriction of the respiratory function. Breaking the lower limbs would prevent the victim from stretching his legs in an attempt to raise his body in order to breathe, thus also hastening death. However, it seems unlikely that this would still have been an important factor at the late stage at which crurifragium was normally performed (Barbet 1963:97).

\subsection{In the case of Christ}

Christ expired within three to six hours, i.e. sooner than was normally the case - as is shown by Pilate's surprise on being informed of the death at three o'clock in the afternoon ${ }^{23}$ — but not exceptionally soon (Edwards et al. 1986:1460). We have reason to believe that Christ was healthy and in the prime of life, although the insufficient rest, food and fluids of the previous 12 hours, along with the debilitating flagellation, would have brought Him to the cross in a state of extreme exhaustion (Du Rand 1993:36). A pulmonary embolism from a venous thrombosis in the leg is unlikely to have precipitated death in such a short time, but cardiac arrest due to a vaso-vagal reflex seems a very probable cause. Among the contributory causes for such a reflex (discussed above), hypoxaemia and acute pain would be the most likely, but pleural puncture by a sharp fractured rib (a late complication of the flagellation) is not impossible. Schulte (1963:186) suggests that death could have been caused by taking the mouthful of sour wine, thus precipitating a pathological reflex coupled to the now discredited "status thymolymphaticus syndrome" (Simpson 1949:558). The sudden influx of a large volume of fluid into the nasopharynx may indeed trigger cardiac arrest by means of a vaso-vagal reflex, but it is most unlikely that

23 Mark 15:44-45. 
Jesus could have taken in enough fluid from the sponge, and in one gulp, to achieve this. It has also been suggested that death could have been caused by a heart infarction as a result of coronary embolisation from aseptic thrombi on the heart valves, which may occur during acute trauma. This is, however, extremely rare (Edwards et al. 1986:1463). It is generally accepted that the soldier's spear was thrust into the heart after death had occurred and did thus not precipitate death. The two thieves appear to have died after Jesus, as a result of crurifragium. ${ }^{24}$

Primrose (1949:386) has argued that since blood and water flowed from the wound in Jesus' side ${ }^{25}$ his blood circulation was still functioning and He could thus not have been dead. This reasoning is flawed, however. Shortly after death, blood does indeed coagulate intravascularly and bleeding is then not possible. But after a period, which can be less than an hour in the case of death from acute hypoxaemia, spontaneous fibrinolysis sets in, dissolving the post mortem thrombi, causing the blood to become fluid again (Gordon \& Shapiro 1975:26, $27,68-70)$, after which it can no longer coagulate. Furthermore, hypoxaemic conditions such as would pertain during crucifixion often lead a watery exudate to ooze into the pleural and pericardial cavities (Barbet 1963:129-147). If Schulte (1963:180) and Edwards et al. (1986:1463) are correct in their assumption that the piercing of Jesus' side by the spear was the standard Roman coup de grâce procedure aimed at the heart, the fluid which flowed from the wound could well have been a mixture of uncoagulable blood from the heart and a watery pericardial (or even pleural) effusion. Blood and water would thus indeed be post mortem confirmation of death.

\section{CONCLUSION}

This article has considered the crucifixion of Christ as a medicohistorical event. Christ was in all probability crucified on a short Tau cross with his feet less than a meter above the ground. He died within six hours, or possibly as few as three, which was a relatively short period, but not exceptionally so. There is thus no reason to postulate extraordinary causes for his death. He probably died of the classic pro-

24 John 19:32.

25 John 19:34. 
gressive asphyxiation syndrome and hypovolaemic shock typical of the crucifixion process, finally brought to an end by cardiac arrest as a result of a vaso-vagal reflex. This could have been precipitated by intense pain from a multiplicity of causes, although hypoxaemia per se, or various other less frequent conditions, could have pertained.

The wound in Christ's side from the spear, which probably pierced his heart, was almost certainly inflicted after death. The appearance of blood and water as an expected post mortem phenomenon has been explained above. There is thus no reason to argue that it indicated a functional cardiovascular system associated with apparent and not real death. Although the two thieves who were crucified with Christ appear still to have been alive at the time of his death, their lives were ended by crurifragium shortly thereafter.

\section{REFERENCES}

\section{BARBET P}

1963. A doctor at Calvary. USA: Image Books Publications.

\section{Celsus}

(see Chadwick).

\section{CHADWICK J}

1965. Origen. Contra Celsum. Cambridge: Cambridge University Press.

COLLINS J J

1939. Archaeology of the crucifixion. Catholic Biblical Quarterly 1:154-9.

DU RAND J

2001. Jesus van Nasaret : wat glo ek? Vereeniging: Christelike Uitgewersmaatskappy.

EdWARdS W D, Wesley J G \& Hosmer F E 1986. On the physical death of Jesus Christ. Journal of the American Medical Association 255(11):1455-63. 


\section{Christ's crucifixion as a medico-historical event}

\section{ESPENAK F}

2001. Solar eclipses of historical interest. [Online] Retrieved from: http://sunearth.gsfc.nasa.gov/eclipse/SEhistory.html.

\section{FITZMYER J A}

1978. Crucifixion in ancient Palestine. Qumran Literature and the New Testament. The Catholic Quarterly 40:493-513.

\section{GORDON I \& SHAPIRO H A}

1975. Forensic Medicine. Edinburgh, London \& New York: Churchill Livingstone.

\section{JOSEPHUS}

1928. The Jewish War Bk. V (transl. H. St. J. Thackeray). London: W. Heinemann. Loeb Classical Library.

1965. Jewish Antiquities (transl. L.H. Feldman). Bk. XVIII. London: W. Heinemann. Loeb Classical Library.

\section{KANE J P}

1990a. Gabbatha. In: J.D. Douglas, N. Hillyer, F.S. Bruce et al. (eds.), New Bible Dictionary ( $2^{\text {nd }}$ ed.). Leicester: Intervarsity Press.

1990b. Burial and mourning. In: J.D. Douglas, N. Hillyer, F.S. Bruce et al. (eds.), New Bible Dictionary ( $2^{\text {nd }}$ ed.). Leicester: Intervarsity Press.

\section{KuHN H-W}

1982. Die Kreuzesstrafe während der frühern Kaiserzeit. In: Aufstieg und Niedergang der römischen Welt 25.1. Berlin: Walter de Gruyter, pp. 649-793.

\section{LONG A}

1998. Attempt to affect the apparent C-14 age of cotton by scorching in a CO2 environment. Radiocarbon 40:1-2.

\section{LUCIANUS}

1935. The passing of Peregrinus et al. (transl. A.M. Harmon). London: W. Heinemann. Loeb Classical Library.

\section{Muller J J}

1976. Die Evangelie van Nikodemus. Deel I: Die Handelinge van Pilatus. In: Nuwe-Testamentiese Apokriewe. Kaapstad: N.G. Kerk Uitgewers.

\section{PAYNE D F}

1990. Calvary. In: J.D. Douglas, N. Hillyer, F.S. Bruce et al. (eds.), New Bible Dictionary ( $2^{\text {nd }}$ ed.). Leicester: Intervarsity Press.

\section{PRIMROSE R}

1949. A surgeon looks at the crucifixion. Hibbert Journal 47:382-8.

\section{SCHWÄr T G, LOUbSer J D \& Olivier J A}

1984. Die ABC van geregtelike geneeskunde. Pretoria: HAUM. 
SCHAEFER B E

1990. Lunar visibility and the crucifixion. Quarterly Journal of the Royal Astronomical Society 31:53-67.

\section{SCHULTE K-J}

1963. Der Tod Jesu in der Sicht der modernen Medizin. Berl. Med. 8:177-220.

\section{SIMPSON K}

1949. Deaths from vagal inhibition. The Lancet 1:558-60.

\section{Spencer Jones J}

1961. General Astronomy (4th ed.). London: Edward Arnold.

\section{SUETONIUS}

1998. The Lives of the Caesars. Divus Claudius (transl. J.C. Rolfe). London: W. Heinemann. Loeb Classical Library.

\section{TACITUS}

1931. Annals (transl. J. Jackson). London: W. Heinemann. Loeb Classical Library.

\section{TORRANCE J B}

1990. Cross, Crucifixion. In: J.D. Douglas, N. Hillyer, F.S. Bruce et al. (eds.), New Bible Dictionary ( $\left.2^{\text {nd }} e d.\right)$. Leicester: Intervarsity Press.

\section{VAN DER WATT J G \& JOUbERT S J}

1996. Hoe is Jesus gekruisig? HTS 52 (4):633-52.

\section{WISEMAN D J}

1990. Calendar. In: J.D. Douglas, N. Hillyer, F.S. Bruce et al. (eds.), New Bible Dictionary (2nd ed.). Leicester: Intervarsity Press.

http://www.shroud.com

http://www.uthscsa.edu/mission/spring96/shroud.htm 


\section{SUPPLEMENTA REEDS GEPUBLISEER SUPPLEMENTA PUBLISHED}

1. Kaleidoskoop 2000, Artikels oor Teologie. Gedenkuitgawe Fakulteit Teologie, UOVS 1980-2000 - D.F. Tolmie (Red.) (2000) (Uit druk/ Out of print)

2. Contemporary translation studies and Bible translation: a South A frican perspective - J.A. Naudé \& C.H.J. van der Merwe (Eds.) (2002)

3. Essentialia et hodierna - Oblata P.C. Potgieter - D.F. Tolmie (Ed.) (2002)

4. Narrative Preaching: theory and praxis of a new way of preaching J. Janse van Rensburg (2003)

5. Ad fontes - teologiese, historiese en wetenskaps-filosofiese studies binne reformatoriese kader — Festschrift vir Ludi F. Schulze -Victor E. d'Assonville, jr. \& Erik A. de Boer (Reds.) (2004)

6. Die Woord verwoord, Artikels oor die Teologie. Eenfeesviering: Universiteit van die Vrystaat - D.F. Tolmie (Red.) (2004) 